\title{
Örgütsel Adaletin Muhasebecilerin İş Memnuniyeti Üzerine Etkisi: Kütahya Örneği
}

Şule SARIKOYUNCU EMRE*

Ahmet AĞCA**

\section{ÖZET}

Çalışmamızda Kütahya'da çalışmakta olan mesleki stajyer ve kurumlara bağlı olarak çalışan muhasebeciler üzerinde örgütsel adaletin iş memnuniyetleri üzerine etkisi, dağıtımsal ve prosedürel adalet boyutları da göz önünde tutulmak suretiyle irdelenmiştir. Araştırma Kütahya'da çalışmakta olan ve rassal olarak seçilmiş kurum ve kuruluşlara bağll olarak çalışan 180 muhasebeciden anket yolu ile elde edilen verilerin analizi sonucunda elde edilmiştir. Araştırma sonucunda Kütahya'da çalışmakta olan muhasebecilerin prosedürel adalet algılarının arttıkça; iş memnuniyetlerinin, örgütsel bağlılıklarının ve performanslarının arttığ tespit edilmiştir.

Anahtar Kelimeler: Örgütsel Adalet, Muhasebe Meslek Grubu, İş Memnuniyeti, Kütahya, Presedürel-Dă̆ıtımsal Adalet

JEL Sinıflandırması: J28, M40, M41, M54. Sample

The Effect Of Organizational Justice On Accountants's Job Satisfaction: Kütahya

\section{ABSTRACT}

The impact of organizational justice on job satisfaction in our work has been examined by considering the dimensions of distributive and procedural justice on accountants under professional internships and institutions, working in Kütahya. Public Accountant, Certified Public Accountant who are working in Kütahya in our work. The study was conducted as a result of analysis of the data obtained by questionnaire of randomly selected 180 accouintants working in Kütahya. As a result of the study, as the perceptions of procedural justice of accountants working in Kütahya increased; it is seen that on their job satisfaction, organizational commitment and performance increase.

Keywords: Organizational Justice, Accounting Profession Group, Job Satisfaction, Kütahya,Presedürel-Distributive Justice.

Jel Classification: J28, M40, M41, M54.

\footnotetext{
* Şule Sarıkoyuncu Emre, Dumlupınar Üniversitesi Sosyal Bilimler Enstitüsü, sarikoyuncu@gmail.com

** Prof.Dr.Ahmet Ağca, Dumlupınar Üniversitesi, İktisadi ve İdari Bilimler Fakültesi, ahmet.agca@dpu.edu.tr
} 


\section{GİRIŞ}

Adalet kavramı insanlık tarihi boyunca üzerinde en fazla durulan ve tanımlanması en güç olan kavramlardan biri olmuştur. Bunun için sayısız teoriler ortaya konulmuştur. Adalet kavramının anlamı, sadece bireyden bireye değil, toplumlara, kültürlere, çağlara, uygarlıklara göre de farklılık göstermektedir. Geçmişte olduğu gibi günümüzde de toplulukların en çok ihtiyacı olan gereksinimlerden biri de adalettir(Solomon, 2004: 21).Bununla birlikte iş yerinde adaletin sağlanması konusu, R. Stacy Adams tarafından 1960 yılında bir kuram olarak geliştirilen "Eşittik Teorisi" ile birlikte ele alınmaya başlanmıştır. Örgütsel adalet, esas olarak çalışanların iş ortamlarındaki eşitlik, bir diğer deyişle adalet algılarıdır. Bunun yanı sıra örgütsel adaleti, işyerinde adaletin sağlanması ve korunmasında otoritenin işlevi olarak da tanımlayan çok sayıda bilim insanı mevcuttur(Cropanzano et al., 2007:9). Örgütler kendilerine ait kültür ve alt kültürlerden meydana gelen topluluklardır (Morgan, 1998: 33). Gelişen sosyal olaylar sonucu, örgütlerin içerisinde insan unsurunun önemi daha da artmaktadır. Böylelikle insana verilen değer ön plana çıkmaktadır. Örgütler sahip oldukları insan gücünü, bilgi çağındaki stratejik güçleri olarak görmektedir. Bu sebeple örgütler bu gücü bünyelerinde tutmaya çalışmaktadır. Bunu yapabilmenin yollarından biri de, örgüt içindeki ilişkilere bağlı olarak ortaya çıkan örgütsel ve kişisel her türlü çıktının, ödül ve cezanın adil dağıtımını ifade eden örgütsel adalettir (Charash ve Spector, 2002: 278). Yani örgütler insan gücünü memnun etmek ve isteklerini yerine getirebilmek için, örgütsel adaleti de sağlamış olmalıdır. Dolayısıyla adaletsizlik hisseden bir çalışan, örgüte karşı olumlu tutum içerisinde olmayacaktır.

$\mathrm{Bu}$ açıdan örgütsel adalet kavramı, hem çalışanların iş tatmini hem de örgütün tam olarak işlevlerini yerine getirebilmesi için son derece önemli olduğundan yönetim, uygulamalı psikoloji, sosyal psikoloji ve örgütsel davranış gibi pek çok farklı alan tarafından irdelenen bir konu olmuştur(Warner vd.,2005:90). Örgütsel ortamda çalışanların adalet algıları hem bireysel hem de örgütsel sonuçlar doğurmaktadır. (Cropanzano et al., 2007:13).Adı geçen çeşitli alanlarda konuyla ilgili yapılan çalışmalarda, örgütsel adaletin iş tatmini, yöneticiye güven, örgütsel vatandaşlık davranışı, örgütsel bağlılık, işe geç kalma, örgütten ayrılma ve işgören hırsızlığı gibi pek çok değişkeni de etkilemekte olduğu ortaya konulmuştur(Gürbüz ve Mert, 2009:118).

Yukarıda yapmış olduğumuz tanımlar çerçevesinde, araştırmacıların örgütsel adaletle ilgili genel olarak dağıtım ve prosedür adaleti türleri üzerinde yoğunlaştıkları görülmektedir. Bununla birlikte çeşitli örgütsel adalet çeşitleri üzerinde de çalışmalar yapıldığ görülmektedir. Dağıtımsal adalet, sonuçlar veya dağıtılanlara ilişkin algılanan adalettir. Odak noktasının çalışanların elde ettiği sonuçlar olması nedeniyle dağıtım adaleti, bilişsel, duygusal ve davranışsal tepkilerle ilişkilidir(Günaydın, 2001: 26-27). Dağıtımsal adalette çalışan, hak ettiğini alıp almadığı sorusunu sormaktadır. Dağıtım adaletinde esas olan, bireylerin dağıtılan kaynaklardan adil şekilde pay aldığını düşünmesidir (Özdevecioğlu, 2003: 78). Prosedürel adalet ise ödül dağıtımına ilişkin kararları almada kullanılan süreçlerde yöneticinin adaleti olarak tanımlanmaktadır(Scandura, 1999:27).Başka bir ifade ile yöneticinin örgüt içinde göstermiş olduğu davranışlar da örgütsel adalet algısı üzerinde etkili olmaktadır. Örgütte ödül ve yapılacak işlerin dağıtımını adil bulmayan çalışan kişi, bu adaletsizliğin yönetici/lider kişiden kaynaklandığını ve onun da bu şekilde olduğu düşüncesine kapılmaktadır (McFarlin ve Sweaney, 1992: 626). Dolayısıyla bir örgüt, çalışanından yüksek bir verim alma beklentisi içerisindeyse örgüt içindeki adaleti de doğru uygulaması gerekmektedir. Luthans(1998), 
çalışanların adalet algılarının ve bağlı olarak motivasyonlarının sadece para ile değil, kuralların uygulanma biçimi, terfi şartları, ödül mekanizmalarından da etkilendiğini belirtmektedir. Bunun için işletmelerde işe alım, oryantasyon, ücret, terfi, performans vb.çeşitli süreçlerin oluşturulması gerekmektedir. Bu süreçlerin oluşma ve uygulanma aşamasında çalışanlar süreçlerle ilgili çeşitli algılamalarda bulunmaktadır. Bu algılamalardan birisi olan adalet çalışanlar arasında sağlandığında onların moral gücü de artmakta ve bu durum iş verimini artırmaya etki etmektedir. Bu durum, çoğalan çalışma alanları ile birlikte artan rekabet ortamında işverenlerin, çalışanlarından verim alabilmeleri için neredeyse en önemli şartlardan biri haline gelmiştir. Yani çalışanlara yüksek moral sağlandığında kurumlar yüksek verim de alabilmektedir(Kalay, 2016).

Örgütsel adalet muhasebe mesleği için de büyük önem arz etmektedir. Çünkü, muhasebecilerin çalıştıkları işyerinden kendi istekleri doğrultusunda olsun olmasın ayrılmaları, örgüt adına maddi manevi pek çok kayıp ve problem yaratmaktadır. Örneğin örgütler, işyerlerinden ayrılan çalışanlarının sahip oldukları bilgileri rakip firmalara taşımaları sonucu rekabet etme avantajlarını yitirme riski ile de karşı karşıya kalabilirler(Zawacki, 1993:73). Ayrıca muhasebe mesleği, teknolojik gelişmelerle birlikte diğer pek çok meslek gurubuna kıyasla çok daha yüksek seviyede teknik bilgi ve eğitim gerektirmektedir(Suvacı ve Subaş1, 2014:3).

Çalışmamızda Kütahya'da çalışmakta olan mesleki stajyer, bağımlı çalışan muhasebecilerin içinde bulundukları örgütteki adalete ilişkin algılarının, dağıtımsal ve prosedür adalet boyutları ile birlikte, iş memnuniyetleri üzerindeki etkisi irdelenmektedir.

\section{TEORIK ÇERÇEVE VE ARAŞTIRMA HIPOTEZLERİ}

Genel itibariyle örgütsel adalet, çalışanın organizasyonun çeşitli uygulama ve faaliyetlerine ilişkin adalet algılaması olarak tanımlanabilir(Greenberg, 1996:24). Başka bir ifade ile çalışanların görev dağılımı, mesaiye uyma, yetki verilmesi, ücret düzeyi, ödül dağılımı gibi değişkenlere yönelik, yönetsel kararları değerlendirme sürecidir. Bu açıdan değerlendirildiğinde örgütsel adaletin, örgüt yönetiminin karar ve uygulamalarının çalışanlar tarafından nasıl algılandığı ile ilgili bir kavram olduğu ifade edilebilir(İnce ve Gül, 2005:76). Ancak diğer taraftan da Taylor'a göre, örgütsel adalet, yöneticilerin ödül, ücret vb. örgütsel çıktıları dağıtırken doğru süreçler izlemeleridir(Masterson, 2000:738). Bu bağlamda örgütsel adalet; yöneticilerin örgüt ve çalışanlarla ilgili karar ve uygulamaları, hem de bu uygulamaların çalışanlar tarafından olumlu şekilde algılanması olarak da tanımlanabilmektedir. Örgütsel adalet, örgüt içerisinde ücretlerin, ödüllerin, cezaların ve terfilerin nasıl yapılacağı, bu tür kararların nasıl alındığı ya da alınan bu kararların çalışanlara nasıl söylendiğinin, çalışanlarca algılanma biçimi olarak tanımlanabilir(İşcan, 2005). Ayrıca örgütsel adalet, yöneticilerin örgütsel uygulama ve kararlarını ve çalışanların bu kararların doğruluğu konusundaki algılarını ve de bu algıların çalışanlar üzerindeki etkilerini kapsar(Çolak ve Hayat, 2004:52).

Örgütsel adalet ile ilgili bilimsel çalışmalar giriş kısmında da belirtilmiş olduğu gibi, R. Stacy Adams tarafından 1960 yılında bir kuram olarak geliştirilen "Eşitlik Teorisi" ile birlikte ele alınmaya başlanmıştır. Eşitlik teorisi, kaynaklara erişim ve kişiler arası ilişkiler açısından eşitliğin adil olup olmadığını inceleyen bir teoridir. Basitçe çalışanların birer kara kutu (black box) olarak görüldügü sistemde, çalışanların iş yerine verdikleri ve aldıkları 
arasındaki ilişkiyi tutmaya çalışır. Buna göre çalışanlar iş yerine bazı girdiler vermektedir ve bunun karşılığında iş yerinden bazı faydalar elde etmektedir. Çalışanların motivasyonu açısından bu alınan/verilen oranını nasıl algıladıkları ve bu algıdaki adalet duygusu önemli bir rol oynamaktadır(Adams, 1965). Çalışanlar, davranışlarını var olan bir durumu algılama biçimlerine göre şekillendirdikleri için çalışanların, örgütün adil olup olmadığına ilişkin algıları örgütsel adalet konusunun önemini artırmaktadır (İşcan, 2005:150). Çalışanlar tarafından örgütlerde adaletsiz bir durumun algılanması olumsuz davranışlara yol açmaktadır. Yöneticilerin çalışanların terfi ya da görev dağılımlarında taraflı bir şekilde davranmaları örgüt içinde performans değerlendirme sistemindeki eşitsizlikler çalışanlarda adalet algısının sarsılmasına neden olmaktadır(İşcan, 2005:150).

Örgütsel adalet algısının çalışanlarda kuvvetli olması durumunda ise, örgütsel verimlilik düzeyi artmaktadır. Ayrıca çalışanların güven, sadakat ve bağlılığını artırdığı gibi iş görenin performansının da artmasını sağlamaktadır. Tüm bunlara ek olarak, çalışanlarda kuvvetli örgütsel adalet algısı, yönetici-çalışan işbirliğinin sağlanmasına olumlu katkılar sağladığı da yadsınmaz bir diğer gerçektir(İşcan, 2005:151).

Örgütsel adalet temel olarak yönetici-çalışan algı ve davranışları ile birinci derecede ilişkili olduğundan, araştırmacıların dağıtımsal ve prosedür olmak üzere örgütsel adalet ile ilgili olarak iki olgu üzerinde yoğunlaştıkları görülmektedir.

\subsection{Dağıtım Adaleti}

Örgütsel adalet kavramı, 1975 yılından önce yapılan çalışmalarda, dağıtımsal adalet açısından incelenmiş ve giriş kısmında da kısaca değinildiği gibi, Adams'ın 'Eşitlik Kuramı" 'bu çalışmaların özünü teşkil etmiştir. Bu bağlamda, dağıtımsal adaletin sonuçlar veya dağıtılanlara ilişkin algılanan adalet olduğunu söylemek mümkündür. Odak noktasının çalışanların elde ettiği sonuçlar olması nedeniyle dağıtım adaleti, bilişsel, duygusal ve davranışsal tepkilerle ilişkilidir (Günaydın, 2001: 26-27). Çalışanlar işleri için bir takım performans girdilerini ortaya koyarlar. Bunlardan birkaçı sahip oldukları eğitim ve tecrübe, işlerinde maruz kaldıkları stres ve gerginliklerdir. Çalışan ortaya koymuş oldukları ile eline geçeni yani sonucu karşılaştırmaktadır. Bu da maaş ve terfi kararlarıdır. Eğer performans girdileri ile aldığı sonuç arasında bir eşitsizlik varsa ve çalışan bunu algılarsa aldığı ödülün adil olmadığını düşünecektir. Dağıtımsal adalette çalışan, hak ettiğini alıp almadığı sorusunu sormaktadır. Çalışanın bu soruya verdiği cevabın ahlaki olması önemlidir. Bu konuda geliştirilmiş nesnel bir ölçüt olmamasına rağmen, çeşitli karşılaştırma ölçütleri vardır. En yaygın olarak kullanılan ise, sosyal yani kıyaslama metodudur. Kişinin, kendisi ile benzer koşullarda olan bir başkasını veya başkalarını kendisi ile karşılaştırmasıdır(Kulik ve Ambrose, 1992: 212-237). Bunun sonucunda kişi, kendisine haksızlık yapıldığı kanısına kapılırsa, işyerinde sergilediği tutum ve davranışları olumsuz yönde etkilenecektir. Bu açıdan dağıtımsal adalette esas olan, bireylerin dağıtılan kaynaklardan adil şekilde pay aldığını düşünmesidir (Özdevecioğlu, 2003: 78).

Dağıtımsal adalet, bireylerin elde ettikleri kazanımların hakça dağıtılıp dağıtılmadığına ilişkin algılamalarıdır. Dağıtım adaletine ilişkin en temel yargı, kazanımların doğru, uygun ve ahlaki olup olmadığıdır(Cropanzano ve Ambrose, 2001; 121). Bu nedenle, bu adalet türünü açıklamaya dönük tüm kurumlar, bireysel uygulamaların adil olup olmadığı yönündeki yargılarını belirlemek üzere kurulmuştur. Çünkü adil dağılım, kazanımların katkılarla oransal olarak eşitliği ilkesinden yola çıkarak tanımlanmıştır (Nam,2003: 36). 
Dağıtım kurallarının nasıl algılandığı, kişilerin karşılaştıkları durumlara göre farklılık gösterebilmektedir. (Özen, 2003: 190).

Dağıtım adaletinde tutarlı olmak, adil olmak kadar önemlidir. Dağıtım kararlarında, önyargıdan uzak, kişisel çıkarlara hizmet etmeyen, doğru bilgiye dayanan bilgiyi kullanmaktır (Jones vd., 1999: 131). Adil ve tutarlı olmak doğrudan ahlak idesi ile ilintilidir. Bu nedenle herhangi bir durum ahlaki ilkelere zarar vermediği sürece adaletsiz olarak algilanamaz. Daha öz bir ifade ile dağıtımsal adalet, insanların nasıl davranması ve diğerleriyle ne şekilde etkileşim içinde olması gerektiğini açıklayan ahlaki bir değerdir (Cropanzano, 2001: 167).

\subsection{Prosedür Adaleti}

Prosedür Adaleti kavramı, literatüre ilk kez Thibaut ve Walker'ın, mahkemede davaların görülmesi sırasında işleyen yasal prosedürlere ilişkin davalıların tepkilerini inceledikleri 1975 yılında yayınladıkları "Procedural Justıce: A Psychological Analysis" adlı eserlerinin yayımlanmasıyla girmiştir. Thibaut ve Walker davalıların, bekledikleri sonuçları elde edemeseler bile, eğer yasal prosedürler adilse sonuçları olumlu algıladıkları kanaatine varmışlardır (Jason vd., 2001:426).

Thibaut ve Walker'ın sözü edilen kitaplarının yayımlanmasının ardından prosedür adaleti üzerine hukuk alanından örgütsel, siyasal, kişiler arası ve eğitimle ilgili ortamlara da taşınmak suretiyle, pek çok çalışma yürütülmüştür. Bu çalışmalarda da Thibaut ve Walker'ın çalışmalarının bulguları doğrulanmıştır (Tyler, 1994:850). Prosedür adaleti kavramı, sosyalyasal alandan örgütsel konulara ise, ilk defa Greenberg ve Folger (1983), Folger ve Greenberg (1985) tarafindan yapılan çalışmalarla taşınmıştır.

Prosedür adaleti, kısaca örgütsel kaynakların dağıtımını belirleyen prosedürlerin algılanan adaleti olarak tanımlanmaktadır (Greenberg, 2000:180). Prosedür adaleti, kısaca karar verme sürecinde etkili olan kişilerin belirlenmesi; ödül sistemi için objektif kuralların belirlenmesi; örgüt içi ödüllendirmelerde gerekli bilgilerin toplanması; karar alma sürecinin yapısı ve içeriğinin açıkça tanımlanması; alınan kararlardan tatmin olmayanlar var ise, tatminsizlik sebeplerinin araştırılması; kaynakların ve ödüllerin dağıtımı sırasında izlenecek yol ve yöntemlerde tutarlığın ve eşitliğin sağlanması olarak tanımlanmaktadır (Chan, 2000:77). Diğer bir ifadeyle prosedür adaleti, maaş, terfi, maddi ve manevi olanaklar, çalışma şartları ve performans değerlemesi gibi unsurların yönetici tarafından belirlenirken uyguladığı politikaların adil olma derecesidir (Chan, 2000:77-78).

Uygulamada iki alt boyutu bulunmaktadır. Formel prosedürler olarak da adlandırılan birincisi, karar alma sürecinde kullanılan prosedürler ve uygulamaların yapısal özellikleriyle ilgili olup, karar alınmadan önce çalışanlara söz hakkı verilmesi, fikir ve görüşlerinin dinlenmesidir. İkincisi ise, yöneticilerin karar alma sürecinde izlediği politika ve uygulanma şeklidir. Bu bağlamda ücret eşitliği ve düzeyi, terfi olanaklarının standarta bağlanması, çalışma şartları, performans değerlemesi, sosyal ve özlük haklarından yararlanma ve sağlanan diğer maddi olanaklar gibi faktörler örgüt çalışanlarının adalet algılarını etkileyen faktörlerdir (Greenberg, 1990: 399).

\section{3. Örgütsel Adalet ve İş Memnuniyeti}

Örgütsel adalet örgütler ve çalışanlar üzerinde önemli etkiye sahiptir. Çalışanlar için çok önemli bir motivasyon kaynağıdır. Çalışanlar kurumlarında kendilerine adil 
davranılmadığını düşünürlerse bu durum iş morallerini düşürerek, iş görme konusunda isteksiz olmalarına, hatta çalıştıkları kuruma karşı misilleme yapmalarına neden olabilmektedir (Folger; Cropanzano, 1998:82). Buna karş1lık işgören işinden, çalışma arkadaşlarından, idarecilerinden, aldığı ücretten memnun ise, terfi olanaklarının kurum içinde adilane bir şekilde işletildiğine inanıyor ise iş memnuniyetleri artar (Moorman, 1991:850). Bu açıdan örgütsel adaletin iş memnuniyeti üzerindeki etkisi çok büyüktür.

Çalışma konumuz olan örgütsel adaletin Kütahya'da kurumlara bağlı olarak çalışan muhasebecilerin iş memnuniyeti üzerindeki olumlu etkisi ile ilgili aşağıdaki hipotez oluşturulmuştur.

H1: Dağıtımsal adaletin Kütahya'da yaşayan muhasebecilerin iş memnuniyeti üzerinde olumlu bir etkisi vardır.

H2: Prosedürel adaletin Kütahya'da yaşayan muhasebecilerin iş memnuniyeti üzerinde olumlu etkisi vardır.

\section{ARAŞTIRMANIN YÖNTEMI}

\subsection{Veri Toplama Süreci ve Örneklem Yapısı}

Araştırmanın örneklemi Kütahya'da mesleki stajyer, çeşitli kurum ve kuruluşlara bağlı çalışan muhasebecileri kapsamaktadır. Kütahya Serbest Muhasebeci Mali Müşavirler Odasından aldığımız bilgiye göre, Kütahya ilinde bağımsız çalışan 89, bağımlı çalışan 192, ticaretle uğraşan 16 , çalışmayan 35 toplamda ise 332 muhasebeci bulunmaktadır. Bu verilere göre aktif görevde olan muhasebeci sayısı 281'dir.Bu muhasebecilerin 60'i bayandır. Araştırmanın uygulama safhası Kasım-Aralık 2016 tarihleri arasında gerçekleştirilmiştir. Hem gruplar halinde toplu olarak, hem teker teker formlar dağıtılmak suretiyle anket gerçekleştirilmiştir. Anketler tüm muhasebecilere ulaşma imkanı olmadığından kurum ve kuruluşlara bağlı olarak çalışan mesleki stajyer ve muhasebeciler arasından 180 kişiye uygulanabilmiştir. Anketlerin tamamı geri toplanabilmiş, ancak bazı anket formlarının ciddiyetten uzak doldurulmuş olması ve eksik cevapların bulunması, pek çok sorunun iki veya daha fazla seçeneğinin işaretlenmesi gibi nedenlerle ancak 140 adet anket formu (\% 50) değerlendirmeye alınmıştır. Bu oran Babbie'ye (1990) göre, anket çalışmaları için kabul edilebilir bir yanıtlama oranıdır. Örneklemin demografik özellikleri Tablo 1'de sunulmuştur.

Tablo 1. Demografik Değişkenlere İlişkin Tanımlayıcı İstatistik Tablosu (N:180)

\begin{tabular}{cccc}
\hline Değişken & Grup & Sayı & Yüzde (\%) \\
\hline \multirow{3}{*}{ Yaş } & 18-30 Arası & 43 & 24 \\
& 31-50Arası & 65 & 36 \\
& 51-60 Arası & 42 & 23 \\
& 60 ve üstü & 30 & 17 \\
\hline \multirow{3}{*}{ Eğitim } & Lise & 22 & 12 \\
& Yüksekokul & 21 & 12 \\
& Lisans & 129 & 72 \\
& Yüksek Lisans & 8 & 4 \\
\hline \multirow{2}{*}{ Cinsiyet } & Kadın & 21 & 12 \\
& Erkek & 159 & 88
\end{tabular}




\begin{tabular}{cccc}
\hline \multirow{2}{*}{ Medeni Durum } & Evli & 138 & 77 \\
& Bekar & 42 & 23 \\
\hline \multirow{3}{*}{ Çalışma Yılı } & $1-10$ & 65 & 36 \\
& $11-20$ & 43 & 24 \\
& $21-30$ & 27 & 15 \\
\multirow{3}{*}{ Ücret } & 30 ve üzeri & 45 & 25 \\
& $1000-1999$ & 44 & 24 \\
& $2000-2999$ & 64 & 36 \\
\hline
\end{tabular}

Tablo 1'den de anlaşılacağı gibi örnekleme katılan katılımcıların \% 24'ünün 18 - 30 yaş arasında, \% 36'sının 31 - 50 yaş arasında, \% 23'ünün 51 - 60 yaş arasında, \% 17'sinin ise 60 yaş ve üzerinde olduğu anlaşılmaktadır. Ayrıca \%80'den fazlası (\%88) erkek olan katılımcıların \% 76'lik bir oranla büyük çoğunluğunun eğitim seviyesinin yüksek olduğu (sadece \% 12 lise mezunu, \% 12 yüksekokul) anlaşılmaktadır.

\section{2.Ölçekler ve Ölçeklerin Güvenilirlikleri \\ 3.2.1.Örgütsel Adalet Ölçeği}

Çalışanların örgütsel adalet algılarını belirlemek üzere Niehoff ve Moorman (1993) tarafindan geliştirilen "örgütsel adalet ölçeği” kullanılmıştır. Söz konusu ölçek hem literatür çalışmalarında sıkça kullanılmakta, hem de çok sayıda atıf almaktadır. Bu çalışmalardan biri de Yıldırım'ın “İs Doyumu ve Örgütsel Adalet”" makalesidir. 20 sorudan oluşan anket soruları bu makaleden alıntılanmıştır(Yıldırım, 2007:278).

\subsection{2. İş Memnuniyeti Ölçeği}

'Minnesota İş Doyumu Ölçeği' kullanılmıştır. İş Doyumu boyutunu belirleyici ölçeğin tespiti konusunda yapılan literatür çalışmasında, incelenen araştırmalar içerisinde en çok kullanılan ölçeğin 'Minnesota İş Doyumu Ölçeği' olduğu saptanmış, bu çalışmada da bahsi geçen ölçek kullanılmıştır. Ölçek, Weiss ve arkadaşları tarafindan 1967 yılında geliştirilmiş, dilimize çevirisi ise 1985 'te Baycan tarafından yapılmıştır. Ölçeğin 100 maddeli uzun ve 20 maddeli kısa olmak üzere iki türü bulunmaktadır. Bunlardan uzun olan ölçekte farklı bölümler ve bu bölümlere özel değerlendirme yöntemleri bulunurken, kısa ölçek 5'li likert tip şeklindedir ve değerlendirilmesinde katılımcının maddeler karşılığında verdiği cevaplara karşılık gelen puanların toplamı ile ya da tüm maddelerden elde edilen puanların toplamının 20'ye bölünmesi ile genel iş doyum skoru elde edilmektedir(Weiss, 1967).Ölçeğin puan sınırları ve karşılıkları, yapısal benzerliği nedeniyle Örgütsel Adalet Ölçeği'nin puan aralığı ile aynıdır. Yine ilgili literatür incelemesi sırasında 'Minnesota İş Doyumu Ölçeği'nin geçerlilik ve güvenirliğini ortaya koyan pek çok çalışmanın olduğu görülmüştür(Baycan, 1985).

\subsection{3.Ödüllendirme Algısı Ölçeği}

Ödüllendirme Algısı Ölçeği, 20 sorudan oluşmakta olup, çalışanların ödüllendirme sisteminin yapısal belirleyicileri ve süreçlerini belirlemek üzere Lawler (2000)'dan yararlanılarak geliştirilmiştir. Lawler'a göre, bir ödüllendirme sisteminin 9 yapısal belirleyicisi ve 2 temel süreç boyutu vardır (Lawler, 2000:40). İfadeler bu görüş referans alınarak oluşturulmuştur. Bunun yanı sıra ekip ödülleri ile ilgili ifadeler Shaw ve diğg. (2001) 
'den alınmıştır (Shaw vd., 2001:911). İletişim sürecine ilişkin ifadeler ise Smidts ve diğ. (2001)’ den yararlanılarak geliştirilmiştir (Yürür, 2005).

\subsection{Güvenilirlik Analizleri}

Örgütsel Adalet Ölçeği için yapılan güvenilirlik çalışmaları neticesinde, tüm ölçeğin Cronbach Alpha iç tutarlılık katsayısı incelenmiştir. Ölçeğin tümü için elde edilen iç tutarlılık katsayıs1 .92 olarak belirlenmiştir. Elde edilen değerler bu ölçeğin güvenilir bir ölçme arac1 olduğunu göstermektedir. Kayış’a (2014) göre cronbach alfa katsayısının .80 ile 1 arasında olması ölçeğin yüksek derecede güvenilir olduğunu göstermektedir.

İş Memnuniyeti Ölçeği için yapılan güvenilirlik çalışmaları neticesinde, tüm ölçeğin Cronbach Alpha iç tutarlılık katsayısı incelenmiştir. Ölçeğin tümü için elde edilen iç tutarlılık katsayısı .94 olarak belirlenmiştir. Elde edilen değerler bu ölçeğin güvenilir bir ölçme aracı olduğunu göstermektedir.

\subsection{Değişkenler Arasındaki İlişkilerin Analizi}

Araştırma kapsamında toplanan verilerin çözümlenmesinde ilk olarak parametrik analiz yöntemlerinin kullanılmasının uygun olup olmadığının belirlenmesi amacı ile basıklık ve çarpıklık değerleri hesaplanmış ve normallik varsayımının karşılanıp karşılanmadığına bakılmıştır. Cooper Cutting (2010) bir veri grubunda çarpıklık değerinin $+2,-2$ aralığında olmasının normal dağılım için kabul edilebilir ölçüt olduğunu ifade etmektedir. Yapılan analizler sonucu üç ölçek için de değerlerin $+2,-2$ aralığında olduğu belirlenmiş, normallik varsayımının karşılandığı sonucuna ulaşılmıştır.

Tablo 2. Ölçek Puanlarının Cinsiyet Değişkenine Göre t-testi Sonuçları

\begin{tabular}{|c|c|c|c|c|c|c|c|}
\hline Ölçekler & Cinsiyet & $\mathrm{N}$ & $\overline{\mathrm{x}}$ & $S$ & Sd & $\mathrm{t}$ & $\mathrm{P}$ \\
\hline \multirow{2}{*}{ Örgütsel Adalet Ölçeği } & Kadın & 21 & 69,0000 & 13,82389 & 178 & .268 & .789 \\
\hline & Erkek & 159 & 68,1950 & 12,80055 & & & \\
\hline \multirow{2}{*}{ İş Memnuniyeti Ölçeği } & Kadın & 21 & 60,0000 & 15,08310 & 178 & 1.570 & .118 \\
\hline & Erkek & 159 & 64,9497 & 13,37852 & & & \\
\hline \multirow{2}{*}{ Ödüllendirme Algısı Ölçeğine } & Kadın & 21 & 73,6667 & 4,60796 & 178 & 2.267 & .026 \\
\hline & Erkek & 159 & 70,2830 & 13,90480 & & & \\
\hline
\end{tabular}

Örgütsel Adalet Ölçeği, İş Memnuniyeti Ölçeği ve Ödüllendirme Algısı Ölçeğine ait toplam puanları cinsiyet değişkenine göre incelendiğine sadece İş Memnuniyeti Ölçeğine ait toplam puanlar arasında anlamlı fark bulunmuştur $(\mathrm{p}<.05)$. Buna göre kadınların ölçekten aldıkları puan toplamı erkeklere göre daha yüksek çıkmıştır. 
Tablo 3. Ölçek Puanlarının Medeni Durum Değişkenine Göre t-testi Sonuçları

\begin{tabular}{|c|c|c|c|c|c|c|c|}
\hline Ölçekler & $\begin{array}{l}\text { Medeni } \\
\text { Durum }\end{array}$ & $\mathrm{N}$ & $\overline{\mathrm{x}}$ & $\mathrm{S}$ & Sd & $\mathrm{t}$ & $\mathrm{P}$ \\
\hline \multirow{2}{*}{ Örgütsel Adalet Ölçeği } & Evli & 138 & 67,8188 & 14,05216 & 178 & .887 & .240 \\
\hline & Bekar & 42 & 69,8333 & 7,87065 & & & \\
\hline \multirow{2}{*}{ İş Memnuniyeti Ölçeği } & Evli & 138 & 63,5217 & 15,22877 & 178 & 1.522 & .018 \\
\hline & Bekar & 42 & 67,1667 & 5,14149 & & & \\
\hline \multirow{2}{*}{ Ödüllendirme Algısı Ölçeğine } & Evli & 138 & 70,2754 & 14,70725 & 178 & .741 & .269 \\
\hline & Bekar & 42 & 72,0000 & 5,95921 & & & \\
\hline
\end{tabular}

Örgütsel Adalet Ölçeği, İş Memnuniyeti Ölçeği ve Ödüllendirme Algısı Ölçeğine ait toplam puanları medeni durum değişkenine göre incelendiğine sadece Ödüllendirme Algısı Ölçeğine ait toplam puanlar arasında anlamlı fark bulunmuştur $(p<.05)$. Buna göre bekar katılımcıların ölçekten aldıkları puan toplamı evli katılımcılara göre daha yüksek çıkmıştır.

Tablo 4. Ölçek Puanlarının Yaş Değişkenine Göre Anova Sonuçları

\begin{tabular}{|c|c|c|c|c|c|c|}
\hline Ölçekler & $\begin{array}{l}\text { Varyansın } \\
\text { Kaynağ1 }\end{array}$ & $\begin{array}{l}\text { Kareler } \\
\text { Toplamı }\end{array}$ & Sd & $\begin{array}{c}\text { Kareler } \\
\text { Ortalaması }\end{array}$ & $\mathrm{F}$ & $\mathrm{P}$ \\
\hline \multirow{3}{*}{$\begin{array}{l}\text { Örgütsel Adalet } \\
\text { Ölçeği }\end{array}$} & Gruplar Aras1 & 1467,608 & 3 & 489,203 & 3,047 & ,030 \\
\hline & Gruplar içi & 28255,370 & 176 & 160,542 & & \\
\hline & Toplam & 29722,978 & 179 & & & \\
\hline \multirow{3}{*}{$\begin{array}{c}\text { Ödüllendirme } \\
\text { Algı̈sı̈ Ölçeğine }\end{array}$} & Gruplar Arası & 1449,825 & 3 & 483,275 & 2,672 & ,049 \\
\hline & Gruplar içi & 31834,237 & 176 & 180,876 & & \\
\hline & Toplam & 33284,061 & 179 & & & \\
\hline \multirow{3}{*}{$\begin{array}{l}\text { İş Memnuniyeti } \\
\text { Ölçeği }\end{array}$} & Gruplar Arası & 417,213 & 3 & 139,071 & ,796 & ,498 \\
\hline & Gruplar içi & 30768,098 & 176 & 174,819 & & \\
\hline & Toplam & 31185,311 & 179 & & & \\
\hline
\end{tabular}

Örgütsel Adalet Ölçeği, İş Memnuniyeti Ölçeği ve Ödüllendirme Algısı Ölçeğine ait toplam puanları yaş değişkenine göre analiz edildiğinde Örgütsel Adalet Ölçeği ve Ödüllendirme Algısı Ölçeğine ait toplam puanlar arasında anlamlı fark bulunmuştur $(\mathrm{p}<.05)$. $\mathrm{Bu}$ değişimin hangi yaş grupları arasında olduğunu belirlemek için LSD çoklu karşılaştırma testi uygulanmıştır. Buna göre Örgütsel Adalet Ölçeğine ait toplam puanlar arasında 18-30 yaş grubu ile 31-50, 51-60 ve 61 ve üzeri yaş grupları arasında anlamlı fark bulunmuştur. Ödüllendirme Algısı Ölçeğine ait toplam puanlar arasında ise 18-30 yaş grubu ile 51-60 ve 61 ve üzeri yaş grupları arasında anlamlı fark bulunmuştur. Bu farkın bütün gruplar için 18-30 yaş grubundaki bireylerin aleyhine olduğu belirlenmiştir.

Tablo 5. Ölçek Puanlarının Eğitim Durumu Değişkenine Göre Anova Sonuçları

\begin{tabular}{|c|c|c|c|c|c|c|}
\hline Ölçekler & $\begin{array}{l}\text { Varyansın } \\
\text { Kaynağ1 }\end{array}$ & $\begin{array}{l}\text { Kareler } \\
\text { Toplamı }\end{array}$ & Sd & $\begin{array}{c}\text { Kareler } \\
\text { Ortalaması }\end{array}$ & F & $\mathrm{P}$ \\
\hline \multirow{3}{*}{$\begin{array}{l}\text { Örgütsel Adalet } \\
\text { Ölçeği }\end{array}$} & Gruplar Arası & 5994,821 & 3 & 1998,274 & 14,822 & ,000 \\
\hline & Gruplar içi & 23728,157 & 176 & 134,819 & & \\
\hline & Toplam & 29722,978 & 179 & & & \\
\hline \multirow{3}{*}{$\begin{array}{c}\text { Ödüllendirme } \\
\text { Algısı Ölçeğine }\end{array}$} & Gruplar Arası & 5687,629 & 3 & 1895,876 & 12,091 & ,000 \\
\hline & Gruplar içi & 27596,432 & 176 & 156,798 & & \\
\hline & Toplam & 33284,061 & 179 & & & \\
\hline
\end{tabular}




\begin{tabular}{cclllll}
\hline \multirow{2}{*}{ İs Memnuniyeti } & Gruplar Arası & 3350,939 & 3 & 1116,980 & 7,063 &, 000 \\
Ölçeği & Gruplar içi & 27834,372 & 176 & 158,150 & & \\
& Toplam & 31185,311 & 179 & & \\
\hline
\end{tabular}

Örgütsel Adalet Ölçeği, İş Memnuniyeti Ölçeği ve Ödüllendirme Algısı Ölçeğine ait toplam puanları eğitim durumu değişkenine göre analiz edildiğinde Örgütsel Adalet Ölçeği, İş Memnuniyeti Ölçeği ve Ödüllendirme Algısı Ölçeğine ait toplam puanlar arasında anlamlı fark bulunmuştur $(\mathrm{p}<.05)$. Bu değişimin hangi eğitim durumuna ait gruplar arasında olduğunu belirlemek için LSD çoklu karşılaştırma testi uygulanmıştır. Buna göre Örgütsel Adalet Ölçeği, Ödüllendirme Algısı Ölçeği ve İş Memnuniyeti Ölçeği'ne ait toplam puanlar arasında lisansüstü grubu ile lise, yüksek okul ve lisans grupları arasında anlamlı fark bulunmuştur. $\mathrm{Bu}$ farkın bütün gruplar için lisansüstü grubundaki bireylerin lehine olduğu belirlenmiştir.

Tablo 6. Ölçek Puanlarının Çalışma Yılı Değişkenine Göre Anova Sonuçları

\begin{tabular}{|c|c|c|c|c|c|c|}
\hline Ölçekler & $\begin{array}{c}\text { Varyansın } \\
\text { Kaynağı }\end{array}$ & $\begin{array}{l}\text { Kareler } \\
\text { Toplamı }\end{array}$ & sd & $\begin{array}{c}\text { Kareler } \\
\text { Ortalaması }\end{array}$ & $\mathrm{F}$ & $\mathrm{P}$ \\
\hline \multirow{3}{*}{$\begin{array}{l}\text { Örgütsel Adalet } \\
\text { Ölçeği }\end{array}$} & Gruplar Arası & 3754,499 & 3 & 1251,500 & 8,482 & ,000 \\
\hline & Gruplar içi & 25968,479 & 176 & 147,548 & & \\
\hline & Toplam & 29722,978 & 179 & & & \\
\hline \multirow{3}{*}{$\begin{array}{l}\text { Ödüllendirme } \\
\text { Alg1sı Ölçeğine }\end{array}$} & Gruplar Arası & 4713,647 & 3 & 1571,216 & 9,679 & ,000 \\
\hline & Gruplar içi & 28570,414 & 176 & 162,332 & & \\
\hline & Toplam & 33284,061 & 179 & & & \\
\hline \multirow{3}{*}{$\begin{array}{l}\text { İş Memnuniyeti } \\
\text { Ölçeği }\end{array}$} & Gruplar Arası & 2575,343 & 3 & 858,448 & 5,281 & ,002 \\
\hline & Gruplar içi & 28609,968 & 176 & 162,557 & & \\
\hline & Toplam & 31185,311 & 179 & & & \\
\hline
\end{tabular}

Örgütsel Adalet Ölçeği, İş Memnuniyeti Ölçeği ve Ödüllendirme Algısı Ölçeğine ait toplam puanları çalışma y1lı değişkenine göre analiz edildiğinde Örgütsel Adalet Ölçeği, İş Memnuniyeti Ölçeği ve Ödüllendirme Algısı Ölçeğine ait toplam puanlar arasında anlamlı fark bulunmuştur $(\mathrm{p}<.05)$. Bu değişimin hangi eğitim durumuna ait gruplar arasında olduğunu belirlemek için LSD çoklu karşılaştırma testi uygulanmıştır.

Örgütsel Adalet Ölçeği ve Ödüllendirme Algısı Ölçeğine ait toplam puanlar arasında 11-20 grubu ile 1-10, 21-30, 30 ve üzeri grupları arasında anlamlı fark bulunmuştur. Bu farkın bütün gruplar için 11-20 grubundaki bireylerin aleyhine olduğu belirlenmiştir.

İş Memnuniyeti Ölçeğine ait toplam puanlar arasında 11-20 grubu ile 1-10, 30 ve üzeri grupları arasında anlamlı fark bulunmuştur. $\mathrm{Bu}$ farkın bütün gruplar için 11-20 grubundaki bireylerin aleyhine olduğu belirlenmiştir.

Tablo 7. Ölçek Puanlarının Ücret Değişkenine Göre Anova Sonuçları

\begin{tabular}{|c|c|c|c|c|c|c|}
\hline Ölçekler & $\begin{array}{c}\text { Varyansın } \\
\text { Kaynağı }\end{array}$ & $\begin{array}{c}\text { Kareler } \\
\text { Toplamı }\end{array}$ & Sd & $\begin{array}{c}\text { Kareler } \\
\text { Ortalamas1 }\end{array}$ & $\mathrm{F}$ & $\mathrm{P}$ \\
\hline \multirow{3}{*}{$\begin{array}{l}\text { Örgütsel Adalet } \\
\text { Ölçeği }\end{array}$} & Gruplar Arası & 9017,434 & 3 & 3005,811 & 25,550 & ,000 \\
\hline & Gruplar içi & 20705,543 & 176 & 117,645 & & \\
\hline & Toplam & 29722,978 & 179 & & & \\
\hline \multirow{3}{*}{$\begin{array}{l}\text { Ödüllendirme } \\
\text { Algısı Ölçeğine }\end{array}$} & Gruplar Aras1 & 7009,727 & 3 & 2336,576 & 15,652 & ,000 \\
\hline & Gruplar içi & 26274,334 & 176 & 149,286 & & \\
\hline & Toplam & 33284,061 & 179 & & & \\
\hline
\end{tabular}




\begin{tabular}{cclllll}
\hline \multirow{2}{*}{ İş Memnuniyeti } & Gruplar Arası & 3296,422 & 3 & 1098,807 & 6,934 &, 000 \\
Ölçeği & Gruplar içi & 27888,889 & 176 & 158,460 & & \\
& Toplam & 31185,311 & 179 & & \\
\hline
\end{tabular}

Örgütsel Adalet Ölçeği, İş Memnuniyeti Ölçeği ve Ödüllendirme Algısı Ölçeğine ait toplam puanları ücret değișkenine göre analiz edildiğinde Örgütsel Adalet Ölçeği, İş Memnuniyeti Ölçeği ve Ödüllendirme Algısı Ölçeğine ait toplam puanlar arasında anlamlı fark bulunmuştur $(\mathrm{p}<.05)$. Bu değişimin hangi eğitim durumuna ait gruplar arasında olduğunu belirlemek için LSD çoklu karşılaştırma testi uygulanmıştır.

Örgütsel Adalet Ölçeğine ait toplam puanlar arasında 2000-2999 TL arası geliri olan katılımcilar ile 1000-1999 TL ve 3000 TL ve üzeri geliri olan katılımcılar arasında anlamlı fark bulunmuştur. Bu farkın bütün gruplar için 2000-2999 TL arası geliri olan katılımcıların lehine olduğu belirlenmiştir.

Ödüllendirme Algısı Ölçeğine ait toplam puanlar arasında 1000-1999 TL arası geliri olan katılımcilar ile 2000-2999 TL ve 3000 TL ve üzeri geliri olan kat1lımcilar arasında anlamlı fark bulunmuştur. Bu farkın bütün gruplar için 2000-2999 TL arası geliri olan katılımcıların lehine olduğu belirlenmiştir.

İş Memnuniyeti Ölçeğine ait toplam puanlar arasında sadece 2000-2999 TL ve 3000 TL ve üzeri geliri olan katılımcılar arasında anlamlı fark bulunmuştur. Bu farkın bütün gruplar için 2000-2999 TL arası geliri olan katılımcıların lehine olduğu belirlenmiştir.

\subsection{Hipotez Testleri}

Korelasyon analizinde muhasebecilerin örgütsel adalet ve iş memnuniyeti arasında birebir ilişkileri temsil eden Pearson korelasyon katsayıları hesaplanmıştır. Analiz sonuçları, örgütsel adalet ve iş memnuniyeti arasında pozitif yönde yüksek düzeyde ilişki(.877) olduğunu göstermektedir. Dolayısıyla örgütsel adalet değişkeninde meydana gelen bir artışın, iş memnuniyetini artıracağını söylemek mümkündür.

Dağıtımsal adalet iş memnuniyetini beklendiği gibi pozitif etkilemektedir. Bu nedenle H1 hipotezi kabul edilmiştir. Prosedürel adalet, iş memnuniyetini pozitif ve istatistiksel olarak anlamlı şekilde etkilemektedir. Yani prosedürel adalet arttıkça, iş memnuniyeti de artmaktadır. Bu durum $\mathrm{H} 2$ hipotezinin desteklendiği anlamına gelmektedir.

Tablo 8. Pearson Korelasyon Katsayıları

\begin{tabular}{lccc}
\hline & & Örgütsel Adalet & İş Memnuniyeti \\
\hline \multirow{2}{*}{ Örgütsel Adalet } & Pearson Korelasyon Katsayısı & 1 & .877 \\
& Anlamlılık & & .000 \\
\hline \multirow{2}{*}{ İş Memnuniyeti } & Pearson Korelasyon Katsayısı & .877 & 1 \\
& Anlamlılık & .000 & \\
\hline
\end{tabular}


Örgütsel adaletin iş memnuniyeti üzerindeki etkilerini ortaya koymak amaciyla kurulan regresyon modelinin $\mathrm{F}$ değeri 595.370, anlamlılık düzeyi $\mathrm{p}<0.05$ 'dir. Buna göre örgütsel adalet iş memnuniyetini \% 77 oranında (düzeltilmiş $\mathrm{R}^{2}=.77$ ) açıklamaktadır.

Tablo 9. Regresyon Analizi Sonuçları

\begin{tabular}{cccc}
\hline \multirow{2}{*}{ Bağımsız Değişken } & \multicolumn{3}{c}{ Bağımlı Değişken } \\
\cline { 2 - 4 } & $\mathrm{B}$ & İş Memnuniyeti & \\
\cline { 2 - 4 } & & $\mathrm{T}$ & $\mathrm{P}$ \\
\hline Sabit & .87 & 3.635 & .000 \\
\hline Örgütsel Adalet Algısı & & 24.408 & \\
\hline $\mathrm{F}$ & & 595.730 & \\
\hline $\mathrm{R}^{2}$ & .770 & \\
\hline $\mathrm{R}^{2}$ (Düzeltilmiş) & & .769 & \\
\hline
\end{tabular}

\section{SONUÇ VE TARTIŞMA}

Günümüzde örgütsel adalet, hem işletmeler ve yöneticileri için, hem de çalışanları için çok önemli bir konudur. Çünkü bir örgüt içerisinde çalışan kişiler çalıştığı örgüte yönelik olarak alg1 ve tutum oluştururken örgütün uyguladığı örgütsel adaletten büyük ölçüde etkilenirler. Çalışanlara uygulanan örgütsel adalet, örgüt üyelerinin psikolojik ve sosyal ihtiyaçlarını tatmin ederek onların örgütle bütünleşmelerini, örgütün amaçlarını benimsemelerini, örgüt bağlılıklarının artmasını, yani örgütü sahiplenmelerini ve dolayısıyla onların daha etkin ve verimli çalışmalarını sağlamaktadır. Dolayısıyla örgütsel adalet, çalışanın örgütten memnuniyet bazında bir doyuma ulaşmasını sağlamakla kalmaz, aynı zamanda örgütün başarısını ve kârını artırır.

Bu noktadan hareketle, Kütahya'da çalışmakta olan Mesleki Stajyer, kurum ve kuruluşlara bağlı çalışan muhasebecilerin işverenlerine ve yöneticilerine duydukları örgütsel adalete ilişkin algıları incelenmiştir. Araştırma Kütahya'da çalışmakta olan ve rassal olarak seçilmiş kurum ve kuruluşlara bağlı çalışmakta olan 180 muhasebeciden anket yolu ile elde edilen verilerin analizi sonucunda elde edilmiştir. Anket çalışmamız esnasında Kütahya'da Serbest Muhasebeci Mali Müşavir Bürolarında genellikle 2 veya 3 çalışan bulunduğu ve ekonomik pazarın da daralmasıyla düşük ücretler verildiği görülmüştür. Serbest Muhasebeci Mali Müşavirlerin ise yaptıkları iş karşılığı mükelleflerinden istedikleri ücreti alamadıkları, ancak yine de bu işi yapmak zorunda oldukları için mecburen mesleğe devam ettikleri anlaşılmıştır.

Araştırma sonucunda elde edilen bulgularla teorik çerçeve ile uyumlu sonuçlara ulaşılmıştır. Araştırma sonuçlarına göre, örgütsel adaletin iki alt boyutu olan prosedürel adalet ve dağıtımsal adalet ile iş memnuniyeti arasındaki ilişki doğrulanmaktadır. Buna göre, Kütahya'da çalışmakta olan muhasebecilerin prosedürel adalet algılarının arttıkça; iş memnuniyetlerinin, örgütsel bağll1ıklarının ve performanslarının arttı̆̆ tespit edilmiştir. Aksi durumda ise, yani örgütsel adaletin işlerlik kazanmadığ 1 kurumlarda iş memnuniyetinin azalacağı ve bunun örgütün kazancına negatif bir şekilde yansıyacaktır. 
Çalışmamızın bulgularına göre, örgütsel adalet iş memnuniyetini \% 77 oranında açıklamaktadır. Bu durum, adaletin iki alt boyutu olan prosedürel adalet ve dağıtımsal adalet ile birlikte istatistiksel olarak da anlamlıdir.

Kütahya ekonomisinde gelişme sağlanırsa, yeni kurulacak Mali Müşavirlik Ortaklık Odaları, Denetim Büroları ve Yeminli Mali Müşavir ortaklıklarında daha fazla çalışan ve daha yoğun ortamda sağlanacak daha iyi çalışma şartları ve daha iyi ücret ve bilgi donanımları ile şirketlere daha iyi hizmet sağlanabilecektir.

\section{KAYNAKLAR}

Adams, J.S. (1965), “Inequity in Social Exchange”, Advances in Experimental Social Psychology, New York:Academic Press, pp.267-299.

Baycan A. (1985), “An Analysis Of The Several Aspects Of Job Satisfaction Between Different Occupational Groups", Sosyal Bilimler Enstitüsü, İşletme Anabilim Dalı. Doktora tezi, İstanbul: Boğaziçi Üniversitesi.

Chan, M. (2000), “Organizational Justice Theories and Landmark Cases”, The International Journal of Organizational Analysis, Vol. 8(1), pp. 68-88.

Charash, C. - Spector, P.E. (2002), “The Role of Justice in Organizations: A Meta-Analysis”, Organizational Behavior and Human Decision Processes, Vol.86, pp.278-321.

Cooper Cutting, J. (2010), "Workplace Stress and Stress Prevention in Europe”, Preventing Stress, Improving Productivity; European Case Studies in the Workplace, Routledge, London: pp.9-32.

Cropanzano R. - Byrne Z.S. - Bobocel R. (2001), "Moral Virtues, Fairness Heuristics, Sosial Entities and Other Denizens of Organizational Justice”, Journal of Vocational Behavior, Vol. 58, pp:164-209.

Cropanzano, R.- Ambrose M.L. (2007), "Procedural and Distributive Justice Are More Similar Than You Think: A Monistic Perspective and a Research Agenda”, Advances In Organizational Justice, Editor: Greenberg, Stanford University Press, StanfordCalifornia, pp. 119-151.

Çolak, M. - Hayat E. E. (2004), "Organizational Justice: A Review of The Literature and Some Suggestions For Future Research”,Hacettepe Üniversitesi İktisadi ve İdari Bilimler Fakültesi Dergisi, S. 22, No:2, ss. 51- 84.

Folger, R. - Cropanzano, R., (1998), Organizational Justice and Human Resource Management, Thousands Oaks, CA: Sage Publications.

Greenberg, J. (1996), The Quest For Justice on The Job:Essays and Esperiments, Thousand Oaks, CA: Sage Publications. 
Greenberg, J. (2000), "Promote Procedural Justice to Enhance Acceptance of Work Outcomes”, The Blackwell Handbook of Principles of Organizational Behavior, Editör. Edwin A. Locke, Blackwell Business, Oxford.

Günaydın, S.C. (2001), İşletmelerde Örgütsel Adalet ve Örgütsel Güven Değişkenlerinin Politik Davranış Algısı ve İşbirliğgi Yapma Eğilimine Etkisini İnceleyen Bir Çalışma, (Basılmamış Yüksek Lisans Tezi), Marmara Üniversitesi Sosyal Bilimler Enstitüsü, İstanbul.

Gürbüz,S - Mert, İ.S.(Eylül 2009), “Örgütsel Adalet Ölçeğinin Geçerlilik ve Güvenilirlik Uygulaması: Kamuda Görgül Bir Çalışma”, Amme İdaresi Dergisi, Cilt:42, Sayı: 3, ss. $117-139$.

İnce, M. - Gül, H. (2005), Yönetimde Yeni Bir Paradigma: Örgütsel Bağlılık, Çizgi Kitapevi, Konya.

İşçan, Ö. F. (2005), “Siyasal Arena Metaforu Olarak Örgütler ve Örgütsel Siyasetin Örgütsel Adalet Algisına Etkisi”, Ankara Üniversitesi Siyasal Bilgiler Fakültesi Dergisi, S.60, No:1,ss.149-171.

Jason, A., Colquitt v.d. (2001), Justice At The Millennium: A Meta-Analytic Review of 25 Years Organizational Justice Research. Journal of Applied Psychology, Vol. 86, No.3, pp. 426-438.

Jones, F., Scarpello, V., Bergmann, T. (1999). “Pay Procedures- What Makes Them Fair?”, Journal of Occupational and Organizational Psychology, Vol. 72, pp. 22-48.

Kalay F.(2016), "İşletmelerde Örgütsel Adaletin işgören Performansı Üzerindeki Etkisi: Teorik Bir İnceleme", Kastamonu Üniversitesi İktisadi ve İdari Bilimler Fakültesi Dergisi, Sayı:11,ss.147-158.

Kulik, C.T. ve Ambrose, M.L. (1992), "Personel and Situational Determinants of Referrent Choice”, Academy of Management Review, Vol.17, pp. 212-237.

Lawler, E. E. (2000). Rewarding Excellence. California, USA, Jossey-Bass Publishers.

Masterson S.S-Lewis K.- Goldman M.B.-Taylor M.S. (2000) “ Integrating Justice and Social Exchange: The Differing Effects of Fair Procedures and Treatment on Work Relationships”, Academy of Management Journal, Vol.43, No.4,pp.738-748.

Luthans, F. (1998)., “Organisational Behaviour” 8th ed. Boston: Irwin McGraw-Hill.

Moorman, R. H. (1991), "Relationship Between Organizational Justice and Organizational Citizenship Behaviors: Do Fairness Perceptions Influence Employee Citizenship?”, Journal of Applied Psychology, Vol.76, No.6, pp. 845-855.

Morgan, G. (1998), Yönetim ve Örgüt Teorilerinde Metafor, Çev: Gündüz Bulut, Mess Yayınları, İstanbul. 
Nam, Dilek(2003), Güven ve Örgütsel Adaletin, Beklenti Ötesi Özyeterlilik Davranışına Etkisi (Basılmamış Yüksek Lisans Tezi), Sakarya Üniversitesi Sosyal Bilimler Enstitüsü, Sakarya.

Özdevecioğlu, M. (2003), “Algılanan Örgütsel Adaletin Bireylerarası Saldırgan Davranışlar Üzerindeki Etkilerinin Belirlenmesine Yönelik Bir Araştırma”, Erciyes Üniversitesi İktisadi ve İdari Bilimler Fakültesi Dergisi, S. 21, pp. 77-96.

Özen J. (2003), “Örgüte Duyulan Güvenin Anahtar Unsuru Olarak Örgütsel Adalet”, Sosyal Bilimlerde Güven, Editör: Ferda Erdem, I. Basım, Vadi Yayınları, Ankara, ss.183-206.

Scandura, T.A. (1999). "Rethinking Leader-Member Exchange: An Organizational Justice Perspective”, Leadership Qurterly, Vol. 10, No. 1, pp. 25-40.

Shaw, J. D.- Duffy, M. K.- Stark, E. M. (2001), "Team Reward Attitude: Construct Development and Initial Validation”, Journal of Organizational Behavior, Vol. 22: pp:903-917.

Solomon, R.C. (2004), Adalet Tutkusu, No:404, Ayrıntı Yayınları, İstanbul.

Suvacı B.- Subaşı Ş.,(2014) “İnsan Kaynakları Yönetiminin Muhasebe Bölümünden ve Muhasebe Eğitiminden Beklentileri”, Akademik Bakış Dergisi, Sayı: 41,ss.1-21.

Tyler, T. R. (1994), "Psychological Models of the Justice Motive”. Journal of Personality and Social Psychology,Vol. 67, pp:850-863.

Warner, C.J.-Hegtvedt, K.-Roman, P. (2005), "Procedural Justice, Distributive Justice: How Experiences With Downsizing Condition Their Impact on Organizational Commitment”, Social Psyhology Quarterly, Vol. 68, No. 1, pp: 89-102.

Yıldırım, F. (2007). "İş Doyumu ve Örgütsel adalet İlişkisi”, Ankara SBF Dergisi. 62:1, ss: 253- 278.

Yürür, Ş. (2005). Ödüllendirme Sistemleri İle Örgütsel Adalet Arasındaki İlişkilerin Analizi ve Bir Uygulama. Yayımlanmamış Doktora Tezi. Uludağ Üniversitesi Sosyal Bilimler Enstitüsü. Bursa.

Zawacki, R A., (1993), “Key Issues in Human Resources Management”, Information Systems Management, Vol. 10, pp. 72-75. 


\section{EK: Anket Örneği}

\begin{tabular}{|l|}
\hline \multicolumn{1}{|c|}{ 1.BÖLÜM DEMOGRAFÍK ( KIŞ̧іSEL) BÍLGÍLER } \\
\hline 1. Yaşınız: ( ) 18-30 ( ) 31-50 ( ) 51-60 ( )61 Üstü \\
\hline 2. Cinsiyetiniz: ( ) Kadın ( ) Erkek \\
\hline 3. Medeni Durumunuz: ( ) Evli ( ) Bekar \\
\hline 4. Eğitim Durumunuz: ( ) Lise ( ) Yüksekokul ( ) Lisans ( ) Lisansüstü \\
\hline 5. Kaç yıldır çalışyorsunuz? : \\
\hline 6. Mevcut iş yerinizde kaç yıldır çalışıyorsunuz? : \\
\hline 7. Ücret Düzeyiniz: ( ) 1000-1999 TL ( ) 2000-2999 TL ( ) 3000 TL Üstü \\
\hline
\end{tabular}

\begin{tabular}{|c|c|c|c|c|c|}
\hline $\begin{array}{l}\text { 3. BÖLÜM } \\
\text { Ödüllendirme Algısı İle İlgili Sorular } \\
\text { Sizden istenen bu ifadelerin sizin açınızdan ne ölçüde doğru olduğunu uygun } \\
\text { yanıt aralığına }(X) \text { işareti koyarak belirtmenizdir. }\end{array}$ & 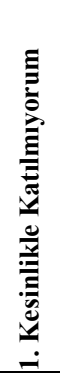 & 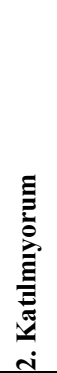 & 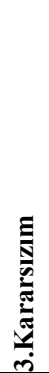 & 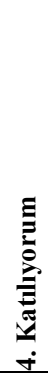 & 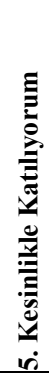 \\
\hline $\begin{array}{l}\text { 1- İş yerimizde yapılan ödüllendirmeler çalışanın yaptığı işin zorluk derecesine } \\
\text { göre verilir. }\end{array}$ & & & & & \\
\hline 2- Ödüller, çalışanın yaptığı işin önemine göre verilir. & & & & & \\
\hline $\begin{array}{l}\text { 3- Ödüller, çalışanların gösterdikleri kişisel gelişme } \\
\text { ( sahip oldukları bilgi ve beceri düzeyindeki gelişmeye ) göre verilir. }\end{array}$ & & & & & \\
\hline $\begin{array}{l}\text { 4- Çalışanlara verilecek ödüllerin belirlenmesinde kişinin bireysel olarak } \\
\text { gösterdiği çaba esas alınır. }\end{array}$ & & & & & \\
\hline $\begin{array}{l}\text { 5- Ödüllerin belirlenmesinde çalışanların ekip olarak gösterdikleri } \\
\text { çaba esas alınır. }\end{array}$ & & & & & \\
\hline $\begin{array}{l}\text { 6- Ekip performansına göre verilen ödüller, ekip üyelerinin yaptığı katkıya } \\
\text { bakılmaksızın üyeler arasında eşit olarak paylaştırılır. }\end{array}$ & & & & & \\
\hline 7- Ekip ödülleri, ekip üyelerinin katkı düzeyine göre farklı miktarda dağıttllır. & & & & & \\
\hline 8- Ekip ödülleri çalışanların farklı ihtiyaçları göz önünde bulundurularak dağıtılır. & & & & & \\
\hline $\begin{array}{l}\text { 9- İş yerimizde çalışanlara verilen ödüller düzenli olarak benzer iş yerleri ile } \\
\text { kıyaslanır. }\end{array}$ & & & & & \\
\hline $\begin{array}{l}\text { 10- Çalışanlara verilen ödüller benzer işyerinin çalışanlarına verdikleri ödüllerden } \\
\text { düşük değildir. }\end{array}$ & & & & & \\
\hline 11- Çalışanlara verilen ödüller terfi ile birlikte artar. & & & & & \\
\hline $\begin{array}{l}\text { 12- Çalışanlara farklı ödül seçenekleri sunularak, kendi ihtiyaçlarına göre seçim } \\
\text { yapma firsatı tanınır. }\end{array}$ & & & & & \\
\hline
\end{tabular}




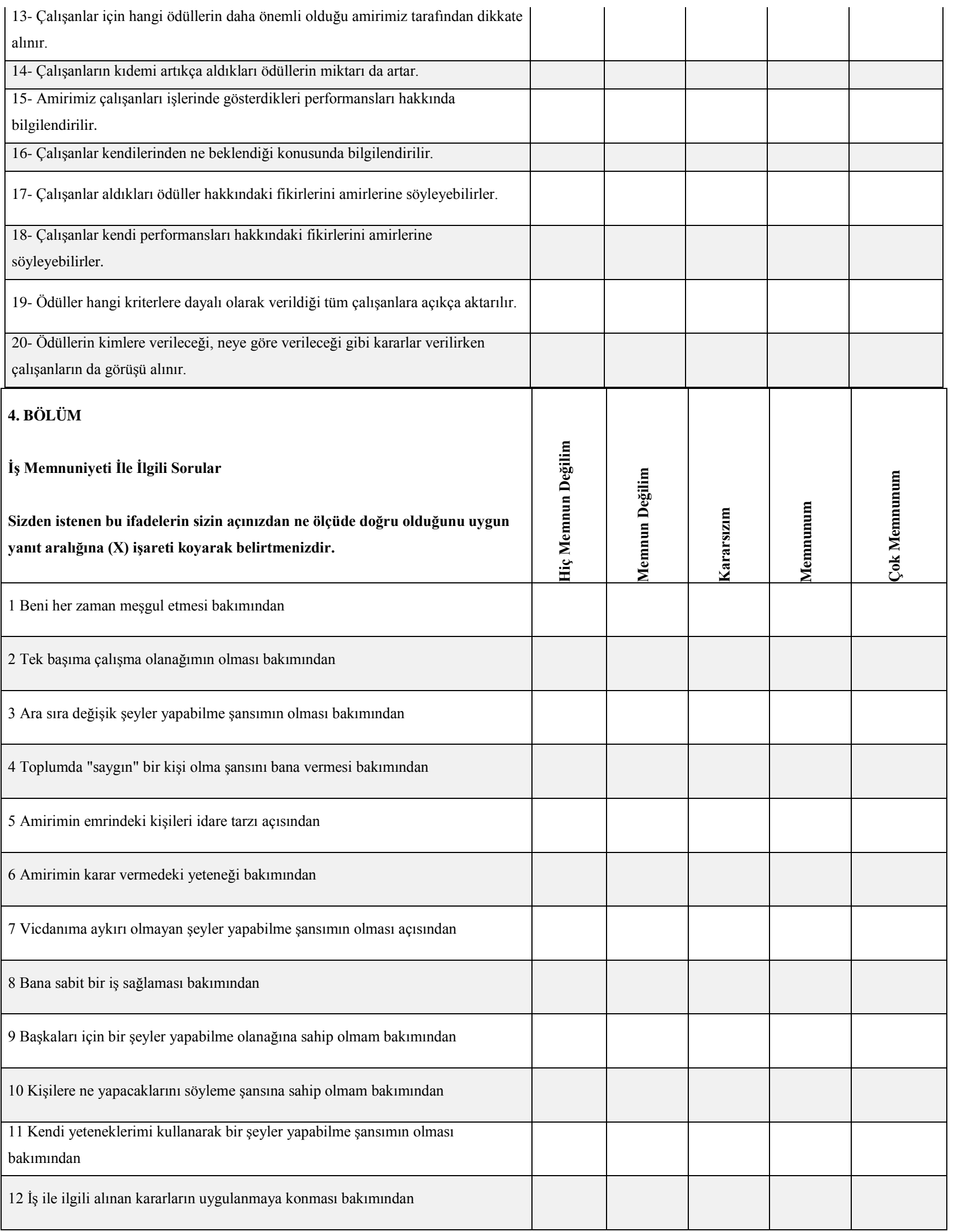




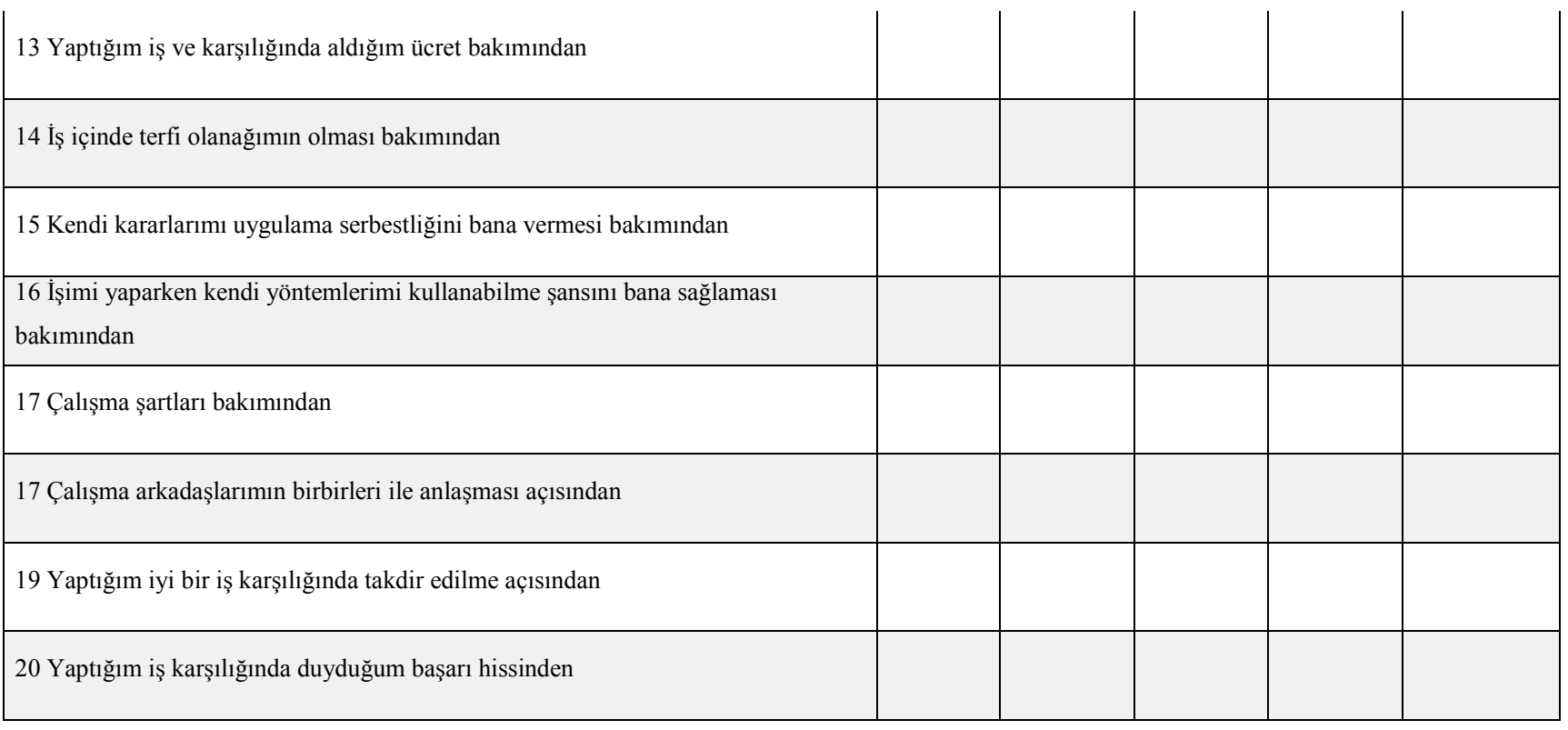

